\title{
HDDM, a formula consisting of seven herbs, had anti-diabetic but no immunomodulatory activities in multiple low doses of streptozotocin-treated female of B6C3F1 mice
}

\author{
Jian Feng Zheng and Tai L Guo* \\ Department of Pharmacology and Toxicology, Virginia Commonwealth University, Richmond, Virginia 23298-6013, USA
}

Received for publication July 28, 2008; accepted February 09, 2009

\begin{abstract}
SUMMARY
The objectives of this study were to determine the effect of herb formula HDDM, a modification of Huangdan decoction that has been shown to be effective in the treatment of glomerulonephritis and chronic renal failure, on the blood glucose levels in multiple low doses (MLD; $50 \mathrm{mg} / \mathrm{kg}$ for five consecutive days) of streptozotocin (STZ)-treated female B6C3F1 mice. Initial studies were performed to compare diabetes induction in five strains (e.g., B6C3F1, NOD, CD-1, C3H/HeN and C57BL/6) of mice by MLD-STZ, and immune changes following the treatment. The results suggested that the order of susceptibility to diabetes induction was NOD $\approx \mathrm{CD}-1>\mathrm{B} 6 \mathrm{C} 3 \mathrm{~F} 1 \approx \mathrm{C} 3 \mathrm{H}$ $>$ C57BL/6. Furthermore, STZ modulation of T cell development, differentiation and activation might play a role in diabetes induction by MLD-STZ treatment. MLD-STZ-induced diabetes in female $\mathrm{B} 6 \mathrm{C} 3 \mathrm{~F} 1$ mice was moderate, which allowed the evaluation of drug-induced protection or exacerbation of diabetes to be performed. As such, modulation of blood glucose by HDDM, which consisted of Da Huang (Radix Et Rhizoma Rhei), Huang Qi (Radix Astragali Seu Hedysari), Dan Shen (Radix Salviae Miltiorrhizae), Yin Yang Huo (Herba Epimedii), Yi Yi Ren (Semen Coicis or Coix lacryma-jobi), Mai Dong (Radix Ophiopogonis) and Shan Zhu Yu (Fructus Corni), was evaluated in MLD-STZ-treated female B6C3F1 mice. The results suggested that HDDM could lower the blood glucose levels, but it had no immunomodulatory activities. Additionally, HDDM-treated mice exhibited improved glucose tolerance. In conclusion, these studies have suggested that MLD-STZ-induced diabetes in female B6C3F1 mice is a useful model to evaluate drug modulation of diabetes, and that the herb formula HDDM possesses anti-diabetic effects.
\end{abstract}

Key words: diabetes; herbs; streptozotocin; B6C3F1 mice

\section{INTRODUCTION}

Diabetic nephropathy $(\mathrm{DN})$ is the single most common cause of end stage renal disease (ESRD) in the United States, and it is the major predictor of

\footnotetext{
*Correspondence: Tai L Guo, Department of Pharmacology and Toxicology, Virginia Commonwealth University, PO Box 980613, Richmond, Virginia 23298-6013, USA. Tel: +8048286732; Fax: +8048285604; E-mail: tlguo@vcu.edu
}

mortality (Striker et al., 1992; Striker and Striker, 1996; Jones et al., 2005). Approximately $40-60 \%$ patients who progressed to ESRD have diabetes (Snyder and Pendergraph, 2005). Both patients with type 1 and type 2 diabetes are prone to the development of DN (Ziyadeh et al., 2000; Hovind et al., 2004; Finne et al., 2005; Rossing et al., 2005; Jorsal et al., 2008; Ziyadeh and Wolf, 2008). Currently, major therapeutic interventions include blood 
glucose control, antihypertensive treatment and dietary protein restriction (Rossing et al., 2005). Despite the success in implementing antihypertensive treatment in patients with type 1 or type 2 diabetes and widespread use of angiotensin-converting enzyme inhibition, no tempering in the rising risk of diabetes-related ESRD has yet appeared in any age categories in the United States population (Chow et al., 2004; Jones et al., 2005). Furthermore, the development of newly onset diabetes mellitus that seems to be initiated by insulin resistance caused by certain antihypertensive regimens has emerged as a strong, independent predictor of allcause mortality (Copley and Rosario, 2005). Therefore, it is important to identify new strategies and additional therapeutic targets for treating DN.

For more than 5,000 years, Chinese herbal medicine (CHM) has helped people live a longer and healthier life. It has been used clinically for over 2,500 years, playing a crucial role in traditional Chinese medicine (TCM). A substantial body of evidence suggests that some Chinese herbs possess a wide range of important pharmacological properties in retarding progressive chronic kidney diseases (CKD; Peng et al., 2005). Development of new strategies using $\mathrm{CHM}$ in the treatment of chronic glomerulonephritis (CG) and chronic renal failure (CRF) can be complementary for, and sometimes even have more advantages than the current therapies because of their less side effects and appropriateness for long-term usage. $\mathrm{CHM}$ can be used in conjunction with current therapies to enhance their therapeutic outcomes and reduce their side effects (Yang et al., 1998; Sun et al., 2000; Song et al., 2007; He et al., 2007). However, ancient TCM practitioners could not measure renal function using parameters such as urinary protein, serum creatinine (Scr) and blood urea nitrogen (BUN), and thus, the attempt to employ TCM to treat CG and CRF according to changes in renal function was not started until 1950s. In 1960s, there was a vigorous debate in Chinese medical fields on treatment of CRF using the concept of promoting circulation and removing blood stasis. After several decades of research, general agreements on the pathogenesis and principles to treat CG and CRF using TCM have been reached, which were to enhance immune defense to eliminate the invading pathogens; to strengthen the function of the Spleen and tonicize the function of the Kidney; and to promote circulation and remove blood stasis and dampness. Our previous studies (both animal and clinical) have demonstrated the efficacy of Huangdan decoction (HDD) or Huangdan capsule (HDC) in the treatment of CG and CRF. In determining the effect of HDD on membranous glomerulonephritis (MGN), the rat model of MGN was established using self-made cationic bovine serum albumin according to Furness' methods (Furness and Turner, 1987). At the 16th week of HDD treatment, decreases in proteinuria, Scr and BUN were apparent when compared to the controls (Zheng and Chen, 1993). HDD-treated groups also displayed less kidney damage as compared to the control group. In determining the effect of HDC on the progression of $C R F$, the 5/6 nephrectomized CRF rat model was employed (Zheng et al., 1997). Fourteen weeks after operation, the levels of BUN and Scr in the 5/6 nephrectomized rats were significantly higher than those in the sham controls. Treatment with HDC significantly attenuated these increases. Additionally, HDC treatment slowed the progression of CRF in the 5/6 nephrectomized rats possibly by increasing the antioxidant activities of superoxide dismutase in renal cortex and erythrocytes, and reducing the levels of lipid peroxidation, plasma cGMP and atrial natriuretic peptide. Furthermore, HDC delayed the damage of remnant kidneys in these rats. In clinical studies (Zheng et al., 1998), patients with CKD were randomly divided into two groups: HDD group (47 cases) and CAO (Coated aldehyde oxystarch) group (38 cases). CAO is commonly used in clinical practices to decrease the level of BUN (Feng et al., 1988). HDD treatment showed efficacy in 28 cases and improvement in 12 cases, and the overall rate 
was $85.1 \%$. CAO treatment showed efficacy in 14 cases and improvement in 8 cases, and the overall rate was $57.6 \%$, which was significantly lower than HDD group.

HDD, which mainly consisted of five herbs, was prepared in such a way that it could strengthen the function of Spleen and tonicize the function of Kidney, promote circulation and eliminate stasis and dampness (Zheng and Chen, 1993). These five herbs were: Da Huang (Radix Et Rhizoma Rhei), Huang Qi (Radix Astragali Seu Hedysari), Dan Shen (Radix Salviae Miltiorrhizae), Yin Yang Huo (Herba Epimedii), Yi Yi Ren [Semen Coicis or Coix lacryma-jobi (Poaceae)]. Da Huang, which was bitter and cold, could activate viscera to eliminate wastes, remove dampness, dispel toxic substances, and remove blood stasis; it worked as the Chief or Principal (Jun) in the formula. Huang Qi, sweet and slightly warm, could invigorate Qi (or energy) to elevate the Spleen Yang, and induce diuresis to alleviate edema; it worked as the Adjuvant (Chen). Yin Yang Huo, which was pungent, sweet and warm, could invigorate Kidney and strengthen Yang, dispel the wind and resolve dampness; it invigorated Yang without causing damage to Yin, and worked as the Adjuvant (Chen). Dan Shen, bitter and slightly cold, removed blood stasis and promoted blood circulation; it worked as the Assistant (Zuo). Yi Yi Ren, sweet and slightly cold, could remove dampness, induce diuresis, and invigorate the Spleen; it worked as the Guide (Shi). Taken together, we have adopted the therapeutic principles by strengthening the host defense and eliminating the invading pathogens for treatment of CG and CRF.

The selection of these herbs could be also justified by their cellular and molecular mechanisms of action. Da Huang inhibited the synthesis of urea in liver and kidneys and decreased the levels of BUN and Scr by reestablishing the balance of amino acids (Wu, 1988). It could also increase the excretion of waste nitrogen through intestines (Chen et al., 1987), prevent the hyperactive metabolism of the remnant kidney in CRF patients and inhibit the proliferation of glomerular mesenchymal cells and renal tubular epithelial cells (Yang et al., 1993, 1994; Yu et al., 1995; Li, 1996). The effectiveness of $\mathrm{Da}$ Huang in CRF patients might also be due to its inhibition on proteinuria (Zhang and el Nahas, 1996), IL-6 production (Song et al., 2000) and fibronectin secretion (Wei et al., 1997), and its antimicrobial activity (Tegos et al., 2002). In addition, Da Huang could antagonize kidney-stimulating factor to restore lipid metabolism (Li, 1991), and it was effective in treating hypertension (Zhang et al., 1994; Wang and Song, 1999). The cholesterol-lowering effect of Da Huang might be attributed to its potent inhibitory activity on squalene epoxidase, a ratelimiting enzyme of cholesterol biogenesis (Abe et al., 2000), and its enhancing effects on the excretion of bile acids and the expression of cholesterol $7 \alpha$ hydroxylase (Goel et al., 1997, 1999). The purified compounds from Da Huang, (-)-epicatechin 3-Ogallate and procyanidin B-2 3,3'-di-O-gallate, could decrease BUN and Scr in rats with adenineinduced renal failure (Yokozawa et al., 1991), and increase glomerular filtration rate, renal plasma flow and renal blood flow (Yokozawa et al., 1993). Interestingly, these gallate compounds could inhibit cholera toxin-induced activities including ADPribosylation, elongation of Chinese hamster ovary cells, and fluid accumulation in ileal loops (Oi et al., 2002). However, single use of Da Huang in CRF patients was discouraged because it required larger doses and induced side effects (Shi et al., 2001; Mantani et al., 2002a,b).

Huang Qi, traditionally used in combination with other Chinese herbs (Peng et al., 2005), contained numerous active components, including flavonoids, polysaccharides, triterpene glycosides (e.g., astragalosides I-VII), amino acids, and trace minerals. Huang Qi could improve renal function by decreasing BUN levels (Zhang et al., 1984; Yang et al., 1997; Zhao et al., 2000), proteinurea, renal fibrosis (Ding et al., 1998) and renal damage (Zhao and Li, 1983; Shi et al., 2002; Peng et al., 2005). 
Huang Qi could retard the progression of CKD using mechanisms such as improving water and sodium retention (Ma et al., 1996; Wang et al., 2002) and modulating the immune responses (Chen et al., 2000; Cai et al., 2001; Jang et al., 2003; Peng et al., 2005), which were independent of the local renal angiotensin system (Yu et al., 2000; Wang et al., 2002; Min et al., 2003).

Yin Yang Huo had vasodilatory effects, and it was especially effective in treating hypertension in patients with kidney diseases $(\mathrm{Wu}, 1982$; Zhao et al., 2007; Xu and Huang, 2007a,b). It warmed Yang and nourished Yin by increasing the expression glucocorticoid receptor (GR) on lymphocytes and GR's affinity for its ligands (Du et al., 2008). Yin Yang Huo treatment also reduced TNF- $\alpha$ production and inhibited NF-кB activity (Xie et al., 2006). Icariin $\left(\mathrm{C}_{33} \mathrm{H}_{40} \mathrm{O}_{15}\right)$, the major flavonoid glycoside in Yin Yang Huo, possessed antioxidative property (Zhao et al., 2007), and could enhance the immune responses (He et al., 1995; Kim et al., 2001). The breakdown of $\mathrm{Ca}^{2+}$ homeostasis in cells was an early and important indicator of cell injury, and the $\mathrm{Ca}^{2+}$ antagonists were being used to treat diseases of hypertension, renal failure, renal colic (Yang et al., 2006). There was evidence that Yin Yang Huo could prevent $\mathrm{Ca}^{2+}$ from entering cells, and facilitate efflux of intracellular $\mathrm{Ca}^{2+}$ by modulating the expression of calmodulin (Jiang et al., 2004; Yang et al., 2006).

Dan Shen could improve microcirculation and increase the glomerular filtration rate. Endothelial nitric oxide synthase in the vascular system has been shown to be a molecular target for Dan Shen in hypertension (Kim et al., 2007). There was evidence that Dan Shen could decrease cyclosporin A-induced expression of TGF- $\beta 1$ and rennin, and the accumulation of matrix proteins in rat kidneys (Qiao et al., 2001). Dan Shen has been shown to decrease renal damage in glycerol-induced acute renal failure in rats (Jin et al., 1997). Magnesium lithospermate B isolated from Dan Shen could inhibit the accumulation of fibronectin in mesangial cell line (Jung et al., 2002) and decrease the blood pressure in rats with sodium-induced hypertension and renal failure, with the latter process being due in part to enhancement of the kallikrein-prostaglandin system (Yokozawa et al., 1992; Chung et al., 1995). An aqueous extract of Dan Shen could inhibit LPSinduced proliferation and endothelin production by mesangial cells (Xu et al., 2001). Dan Shen also exerted a protective effect against renal cell injury, and its effect might be due to its antioxidant action (Yokozawa and Chen, 2000; Jeong et al., 2001). In post-operative patients with obstructive jaundice, Dan Shen protected renal function by inhibiting the release of inflammatory mediators and improving blood dynamics (Peng et al., 2001).

Yi Yi Ren could induce diuresis and modulate immunity (Chen et al., 1987; Kim et al., 2004). The active ingredients from Yi Yi Ren (Kang-Lai-Te) could inhibit mesangial cell proliferation (Hu et al., 2005). There were evidences that Yi Yi Ren could suppress the production of IgE against injected antigen ovalbumin in a mouse model (Shyu et al. 1998) by shifting the immune balance from Th2 to Th1 (Hsu et al. 2003). On the other hand, ingestion of Yi Yi Ren could increase the number of cytotoxic T-lymphocytes (CD3+, CD56+) and natural killer (NK) cells (CD16+, CD57-) in humans (Hidaka et al., 1992). Using a NF-кB-dependent reporter assay, Woo et al. (2007) demonstrated a dose-dependant inhibition of NFKB signaling by Yi Yi Ren extract, which was associated with a reduced translocation of the Rel-A/p65 subunit of NF- $\kappa B$ to the nucleus. Additionally, Yi Yi Ren extract also inhibited the activity of protein kinase $\mathrm{C}$, a major mediator of signal transduction and activator of NFkB (Woo et al., 2007). Yi Yi Ren also possessed anti-oxidant activity (Kuo et al., 2002; Huang et al., 2005) and inhibited nitric oxide and superoxide production (Seo et al., 2000). Yi Yi Ren could lower fibrinogen levels and reduce fibrinolytic activity in Wistar rats (Check and K'Ombut, 1995), which was important since increased fibrinogen levels have been associated with reduced kidney functions in 
individuals with stage 3 to 4 CKD (Weiner et al., 2008).

It is also possible that HDD possesses the properties to retard the progression of $\mathrm{DN}$. Glucose transporter-1 (GLUT1) is a membraneembedded protein that mediates the uptake of glucose into the cells. TGF- $\beta 1$ stimulates glucose uptake by enhancing the expression and function of GLUT1 in cultured mesangial cells, resulting in excessive glucose consumption and the production of extracellular matrix in DN (Zhang et al., 2000). Huang Qi has been shown to significantly reduce proteinuria in $\mathrm{DN}$ patients with massive macroalbuminuria (Chen et al., 1998; XY et al., 1999) and diabetic renal hypertrophy in experimental animals (Xu et al., 1997). Huang Qi can upregulate the expression of hepatocyte growth factor (HGF) that further inhibits glucose-induced overexpression of TGF- $\beta 1$ in human kidney fibroblast cells (Peng et al., 2005). There are also substantial amount of evidences to demonstrate that Da Huang can retard the progression of DN (Dai et al., 1999; Guo et al., 2002a,b; Zhu et al., 2002). Da Huang can antagonize the effect of TGF- $\beta 1$ in mesangial cells to reduce the expression of GLUT1 (Zhang et al., 1999). The purified compound emodin (3-methyl1,6,8 trihydroxyanthraquinone) from Da Huang can decrease the gluconeogenesis of tubular cells (Li, 1996a) and inhibit postprandial hyperglycemia (Choi et al., 2005), and it can decrease glucoseinduced matrix synthesis in human peritoneal mesothelial cells and cultured mesangial cells (Chan et al., 2003). Hexosamine biosynthesis pathway plays an important role in the development of insulin resistance. Da Huang inhibits the activity of fructose 6-phosphate aminotransferase, a ratelimiting enzyme in the hexosamine pathway, in mesangial cells. Yi Yi Ren can decrease the concentration of leptin (Huang et al., 2005) and the lipid components in plasma and feces in rats fed high fat and cholesterol diet (Kim et al., 2004), which are responsible for its anti-obesity effects (Kim et al., 2007a). Yi Yi Ren-containing formula has insulin-like action and insulin sensitizer property in type 2 diabetic models (Chang et al., 2006). Coixans A, B, and C isolated from Yi Yi Ren have hypoglycemic activity in rats (Takahashi et al., 1986). Supplementation with Yi Yi Ren has also decreased plasma lipids and inhibited LDL oxidation in hyperlipidemic individuals ( $\mathrm{Yu}$ et al., 2004). It is likely that the combination of Huang Qi, Da Huang and other herbs in HDD may exert a greater protective effect on diabetic renal damage. It would be a great advantage if an herb formula that was designed to treat $\mathrm{DN}$ could also reduce the blood glucose level. This study reported here represented a first series of our attempts to address this issue. Mai Dong (Ophiopogon; Radix Ophiopogonis) and its components have been used to reduce blood sugar (Chen et al., 1998; Wu et al., 2006); Shan Zhu Yu (Fructus Corni) could suppress hepatic gluconeogenesis-related gene transcription, enhance pancreatic $\beta$-cells glucose responsiveness, and prevent toxin-induced $\beta$-cell death (Chen et al., 2008). Therefore, in addition to HDD, a modified HDD (HDDM) that included additional herbs such as Mai Dong and Shan Zhu Yu has been tested in a multiple low doses (MLD) streptozotocin (STZ)induced diabetic model. We used B6C3F1 mouse, a hybred of male $\mathrm{C} 3 \mathrm{H} / \mathrm{HeN}$ and female C57BL/6, in our studies because it was preferred over randomly bred mice in order to decrease the variation between individual animal's responses and reduce the number of animals for each experiment, and yet have the vigor associated with the heterozygosity. Furthermore, our data on several strains of mice (NOD, CD-1, C3H/HeN, C57BL/6 and B6C3F1) have suggested that MLD-STZ-induced diabetes in B6C3F1 mice was moderate, and this model had the ability to detect either protection or exacerbation of diabetes by the treatments.

\section{MATERIALS AND METHODS}

\section{Animals}

Female NOD and B6C3F1 mice (6 - 8 week old) 
were purchased from Taconic Farms (Germantown, $\mathrm{NY}$ ), and female CD-1, C3H/HeN and C57BL/6 mice (6-8 week old) from Charles River Laboratories. Animals were quarantined for at least a week prior to use. Mice were randomized by weight, earpunched for identification, and transferred to plastic shoebox cages ( 3 - 4 animals per cage) for testing. The cages were bedded with hardwood sawdust and covered with a filter bonnet; mice were provided with tap water and fed certified Zeigler rodent chow ad libitum for the duration of the study. Room temperature was maintained at $22-24^{\circ} \mathrm{C}$, and the relative humidity between 40 and $70 \%$. The light/dark cycle was maintained on $12 \mathrm{~h}$ intervals. Mice were determined to be free of hepatitis and Sendai virus by serology testing. All animal procedures were conducted under an animal protocol approved by the VCU Institutional Animal Care and Use Committee (IACUC).

\section{Treatment with STZ}

For STZ treatment, female mice (NOD, CD-1, B6C3F1, C3H/HeN and C57BL/6) were injected (i.p.) with STZ (Sigma-Aldrich) solutions, prepared immediately before use, in citrate buffer ( $\mathrm{pH} 4.5$ ). The dosing regimen for STZ consisted of five consecutive daily $50 \mathrm{mg} / \mathrm{kg}$ doses. The vehicle $(\mathrm{VH})$ group received the same amount of $0.1 \mathrm{M}$, pH 4.5 citrate buffer (i.p.) for five consecutive days as detailed by the NIDDK Consortium for Animal Models of Diabetic Complications' (AMDCC) protocol (available from http:/ / www.amdcc.org).

\section{Herb preparation and dosing}

The herb extracts in powder form were purchased from Crane Herb Company (Mashpee, MA). These herbs were mixed well and resuspended in distilled water and heated to dissolve, and administered at dose of $1000 \mathrm{mg} / \mathrm{kg}$ by gavage daily. The formulation of HDD has been reported previously (Zheng and Chen, 1993). For HDDM, two additional herbs Mai Dong and Shan $\mathrm{Zhu} \mathrm{Yu}$ were included, and the percentages of both herbs were $22 \%$.

\section{Measurement of blood glucose levels}

Monitoring of glycemic status was performed prior to the beginning of treatment to ensure that there were no significant differences between groups in blood glucose levels and no outlier animals. Thereafter, the animals were monitored for blood glucose changes every week for STZ-treated mice. Non-fasting blood glucose was measured directly in small samples of venous blood using Accu-Chek Diabetes monitoring kit (Roche Diagnostics, Indianapolis, IN). Mice with a serum blood glucose concentration above $250 \mathrm{mg} / \mathrm{dl}$ were considered diabetic and above $400 \mathrm{mg} / \mathrm{dl}$ were considered as severely diabetic as described by Li et al. (2001).

\section{Glucose Tolerance Test (GTT)}

For GTT, a fasting blood sample was taken from all groups of mice. Four more blood samples were collected at 30, 60, 90, and 120 min intervals after administration (i.p.) of a sterile glucose solution at the dose of $2 \mathrm{~g} / \mathrm{kg}$ of body weight.

\section{Cell isolation and determination of cell number}

The quantification of splenocyte subsets was performed as previously described (Auttachoat et al., 2007). Single cell suspensions of individual spleens were prepared by mashing the excised organs between the frosted ends of two microscope slides. After washing, cells were resuspended in RPMI complete medium and counted using a Coulter Counter ZII with the red blood cells lysed by a ZAP-O-GLOBIN II lytic reagent (Coulter Corporation, Miami, FL).

\section{Flow cytometric analysis}

Splenocytes and thymocytes were labeled with the appropriate monoclonal antibody (mAb), conjugated directly with a fluorescent molecule for visualization. Cells were dual stained with phycoerythrin (PE)conjugated antibody and fluorescein isothiocyanate (FITC)-conjugated antibody or three-way stained using antibodies conjugated with FITC, PE and peridinin chlorophyll protein (PerCP). The antibodies 
were purchased from BD PharMingen (San Jose, $\mathrm{CA})$. The $\mathrm{mAb}$ used were anti-mouse Ly-6G (Gr-1) conjugated with FITC, anti-mouse IgM with FITC, anti-mouse CD8 with $\mathrm{PE}$, anti-mouse CD4 with FITC or PerCP, anti-mouse CD3e with PerCP, antimouse NK1.1 with PE and anti-mouse Mac-3 with PE. The antibodies were diluted (1:80) in 50\% fetal bovine serum-phosphate buffered saline (FBSPBS). Isotype-matched irrelevant antibodies were used as controls. Following the addition of the reagents, the cells were incubated at $4{ }^{\circ} \mathrm{C}$ in the dark for at least $30 \mathrm{~min}$. Thereafter, the cells were washed $2 X$, and enumeration performed on a Becton Dickinson FACScan Flow Cytometer in which $\log$ fluorescence intensity was read with a forward scatter threshold high enough to eliminate red blood cells. The data were analyzed using CELLQuest software. A minimum of 5,000 events was acquired.

\section{Natural killer cell activity}

The activity of NK cells was assayed as described (Reynolds and Herberman, 1981) with modification. Single cell suspensions were adjusted to four concentrations: $1 \times 10^{7}, 5 \times 10^{6}, 2.5 \times 10^{6}$ and $1.25 \times$ $10^{6}$ cells $/ \mathrm{ml}$. The target cells, YAC- 1 cells, were labeled with ${ }^{51} \mathrm{Cr}$ and added to each well of a 96well plate in a volume of $0.1 \mathrm{ml}$. The effector cells $(0.1 \mathrm{ml})$ were added to each of two replicate wells of target cells at each effector concentration to obtain effector:target (E:T) ratios of 100:1, 50:1, 25:1, and 12.5:1. The spontaneous release and the maximum release were determined by adding 0.1 $\mathrm{ml}$ of medium and Triton X-100 (0.1\%) to each of 12 replicate wells containing the target cells, respectively. Following $4 \mathrm{~h}$ incubation, the plates were centrifuged, and $0.1 \mathrm{ml}$ of the supernatant was removed from each well and the radioactivity counted. The mean percentage of cytotoxicity at each E:T ratio was determined.

Anti-CD3 antibody-mediated spleen $T$ cell proliferation The proliferation of splenocytes in the presence of
anti-CD3 antibody was performed as described (Guo et al., 2001). Briefly, a single spleen cell suspension was prepared and resuspended in RPMI medium (Roswell Park Memorial Institute) supplemented with fetal bovine serum (FBS; 10\%), sodium bicarbonate, HEPES, L-glutamine, gentamicin and 2-mercaptoethanol $(0.00035 \%)$. The splenocytes $(2 \times 105 /$ well $)$ were cultured in the microtiter wells coated with anti-CD3 antibody $(1 \mathrm{mg} / \mathrm{ml}$; Phar Mingen) or in wells without antibody coating at $37^{\circ} \mathrm{C}$ at $5 \% \mathrm{CO}_{2}$ and $95 \%$ humidity. Prior to harvest on day 3 , the cells were pulsed with ${ }^{3} \mathrm{H}$ thymidine for $18-24 \mathrm{~h}$. The incorporation of ${ }^{3} \mathrm{H}-$ thymidine into the proliferating cells was used as the endpoint of the assay, and the data were expressed as $\mathrm{CPM} / 2 \times 10^{5}$.

\section{Statistics}

The data were expressed as mean \pm S.E. The results were tested for variance homogeneity using Bartlett's Test, and all the data reported here were homogeneous. Homogeneous data were analyzed using a one-way analysis of variance; when significant, Dunnett's $t$ Test was used to determine differences between the experimental and vehicle control group. For diabetes incidence, the Fisher's Exact Test was used to determine if a group was statistically significant from the control group. A group was considered statistically significant from the control group if $P<0.05$.

\section{RESULTS}

\section{Induction of diabetes in female $\mathrm{B} 6 \mathrm{C} 3 \mathrm{~F} 1, \mathrm{C} 3 \mathrm{H} / \mathrm{HeN}$, C57BL/6, CD-1 and NOD mice by MLD-STZ}

To determine the strain difference in MLD-STZinduced diabetes, female mice of five strains were included: $\mathrm{B} 6 \mathrm{C} 3 \mathrm{~F} 1, \mathrm{C} 3 \mathrm{H} / \mathrm{HeN}, \mathrm{C} 57 \mathrm{BL} / 6, \mathrm{CD}-1$ and NOD. Among them, NOD and CD-1 were the most susceptible strains (Fig. 1). Treatment with MLD-STZ produced a marked increase in the incidence of diabetes in female NOD mice (Fig. 1A). Of eight NOD mice in the group, five mice 

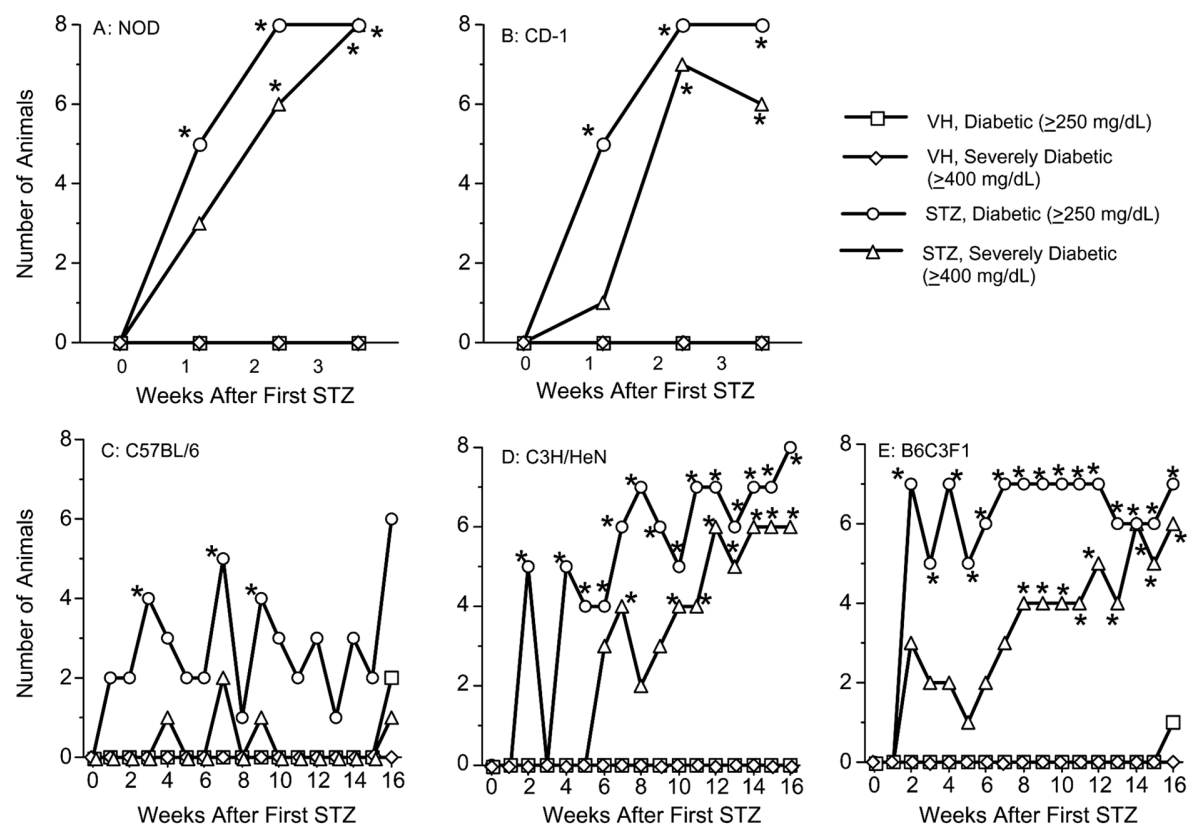

Fig. 1. Strain differences in MLD-STZ-induced diabetes. (A) Female NOD mice, (B) female CD-1 mice, (C) female C57BL/ 6 mice, (D) female $\mathrm{C} 3 \mathrm{H} / \mathrm{HeN}$ mice, and (E) female B6C3F1 mice. Animals were treated with MLD-STZ (50 mg/ kg for five consecutive days); the development of diabetes monitored for 3 weeks for NOD and CD-1 mice, and 16 weeks for $\mathrm{C} 57 \mathrm{BL} / 6, \mathrm{C} 3 \mathrm{H} / \mathrm{HeN}$ and $\mathrm{B} 6 \mathrm{C} 3 \mathrm{~F} 1$ mice as described. ${ }^{*} P \leq 0.05$ when compared to vehicle $(\mathrm{VH}) . \mathrm{N}=8$.

developed diabetes at week 1 after the first STZ injection, and all mice developed diabetes at week 2 after the first STZ injection. Six of the eight NOD mice developed severe diabetes at week 2 after the first STZ injection, and all mice developed severe diabetes at week 3 after the first STZ injection. For CD-1 strain (Fig. 1B), five of the eight CD-1 mice developed diabetes at week 1 after the first STZ injection, and all mice developed diabetes at week 2 after the first STZ injection. Seven of the eight CD-1 mice developed severe diabetes at week 2 after the first STZ injection, and six of the eight mice developed severe diabetes at week 3 after the first STZ injection. On the other hand, C57BL/ 6 was the least susceptible strain (Fig. 1C): In the period of 16 weeks, the incidence of diabetes only reached the levels of statistical significance at three time points, e.g., week 3,7 and 9 following the first STZ injection, when compared to the vehicle control; the incidence of severe diabetes was not significantly changed at any time points. The susceptibilities of $\mathrm{C} 3 \mathrm{H} / \mathrm{HeN}$ and $\mathrm{B} 6 \mathrm{C} 3 \mathrm{~F} 1$ mice were identical (Fig. 1D and 1E): when compared to the control, the incidence of diabetes reached the levels of statistical significance for 14 and 15 times in the assessed 16 time points for $\mathrm{C} 3 \mathrm{H} / \mathrm{HeN}$ and B6C3F1 mice, respectively; the incidence of severe diabetes reached the levels of statistical significance for 8 and 9 times in the assessed 16 time points for, $\mathrm{C} 3 \mathrm{H} / \mathrm{HeN}$ and $\mathrm{B} 6 \mathrm{C} 3 \mathrm{~F} 1$ mice, respectively.

MLD-STZ treatment produced decreases in the terminal body weights in mice of all these strains (Table 1). Increases in the weights of liver were observed in mice of both the $\mathrm{C} 3 \mathrm{H} / \mathrm{HeN}$ and B6C3F1 strains following the MLD-STZ treatment. MLD-STZ treatment also produced a decrease in spleen weight in NOD mice. No significant changes were observed for the weights of spleen, and kidneys in mice of any other strains (Table 1). 
Table 1. MLD-STZ treatment on body weight and organ weights in female mice of various strains

\begin{tabular}{cccccc}
\hline Mouse Strains & Treatment & Body Weight $(\mathrm{g})$ & Spleen $(\mathrm{mg})$ & Kidneys $(\mathrm{mg})$ & Livers (mg) \\
\hline \multirow{2}{*}{ NOD } & VH & $24.1 \pm 0.6$ & $72.0 \pm 2.3$ & $\mathrm{ND}$ & ND \\
& MLD-STZ & $17.8 \pm 0.6^{*}$ & $54.3 \pm 2.6^{*}$ & $\mathrm{ND}$ & ND \\
\hline \multirow{2}{*}{ CD-1 } & VH & $28.2 \pm 0.5$ & $107.0 \pm 9.3$ & $\mathrm{ND}$ & ND \\
& MLD-STZ & $24.1 \pm 0.3^{*}$ & $113.1 \pm 7.2$ & $\mathrm{ND}$ & ND \\
\hline \multirow{2}{*}{ C57BL/6 } & VH & $29.6 \pm 1.3$ & $97.3 \pm 4.8$ & $343.8 \pm 18.6$ & $1156.3 \pm 75.3$ \\
& MLD-STZ & $25.7 \pm 0.8^{*}$ & $104.1 \pm 4.1$ & $301.1 \pm 12.9$ & $1282.9 \pm 64.7$ \\
\hline \multirow{2}{*}{ C3H/HeN } & VH & $35.2 \pm 1.5$ & $135.8 \pm 14.2$ & $437.8 \pm 20.8$ & $1477.1 \pm 102.8$ \\
& MLD-STZ & $27.2 \pm 0.7^{*}$ & $129.9 \pm 9.0$ & $460.5 \pm 20.6$ & $1813.9 \pm 63.6^{*}$ \\
\hline \multirow{2}{*}{ B6C3F1 } & VH & $32.7 \pm 2.1$ & $80.0 \pm 3.3$ & $378.8 \pm 13.2$ & $1150.1 \pm 29.2$ \\
& MLD-STZ & $25.2 \pm 0.5^{*}$ & $88.6 \pm 3.4$ & $394.9 \pm 18.9$ & $1370.5 \pm 85.2^{*}$ \\
\hline
\end{tabular}

Animals were sacrificed three weeks after the first STZ injection for NOD and CD-1 mice, and after 16 weeks for mice of other strains. ND $=$ not determined. ${ }^{*} P \leq 0.05$ when compared to vehicle $(\mathrm{VH}) . \mathrm{N}=8$.

Immunomodulation in female B6C3F1, C3H/HeN, C57BL/6, CD-1 and NOD mice by MLD-STZ

MLD-STZ-induced diabetes is considered a disease of immune origin since it is associated with a secondary autoimmune insulitis following apoptotic injury of the pancreatic $\beta$-cells by STZ in contrast to diabetes induced by a single high dose of STZ $(-200 \mathrm{mg} / \mathrm{kg})$ that causes a direct death of islet $\beta$-cells (Like and Rossini, 1976; Ablamunits et al., 1999). Three assays were conducted to determine if MLD-STZ treatment would affect the immune response in mice of these strains: anti-CD3 antibodymediated splenocyte proliferation, NK cell activity assay and flow cytometric analysis of differential splenocytes. Increases in both the basal and antiCD3 antibody-mediated splenocyte proliferation
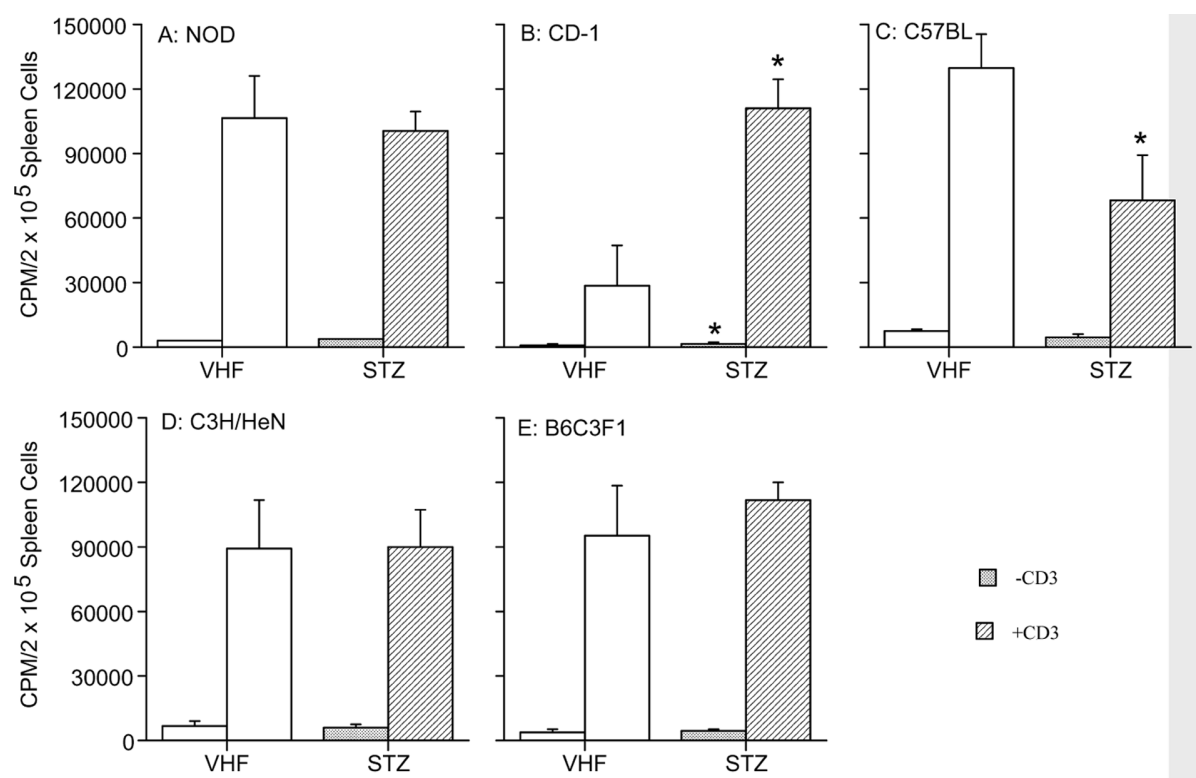

$\square-\mathrm{CD} 3$

曰 $+\mathrm{CD} 3$

Fig. 2. Modulation of anti-CD3 antibody-mediated splenocyte proliferation in female NOD (A), CD-1 (B), C57BL/ 6 (C), C3H/HeN (D) and B6C3F1 (E) mice following MLD-STZ treatment. Animals were sacrificed three weeks after the first STZ injection for NOD and CD-1 mice, and 16 weeks for mice of other strains; splenocyte proliferation was determined in the presence or absence of anti-CD3 antibodies as described. ${ }^{*} \leq 0.05$ when compared to vehicle (VH). $\mathrm{N}=8$. 
were observed in CD-1 mice following MLD-STZ treatment (Fig. 2B). On the other hand, a decrease in anti-CD3 antibody-mediated splenocyte proliferation, but not the basal splenocyte proliferation, was observed in the C57BL/ 6 mice following MLDSTZ treatment (Fig. 2C). No significant changes were produced in either the basal or anti-CD3 antibody-mediated splenocyte proliferations in mice of the other three strains: $\mathrm{NOD}, \mathrm{C} 3 \mathrm{H} / \mathrm{HeN}$ and B6C3F1 (Figs. 2A, D and E).

Treatment with MLD-STZ did not affect the NK

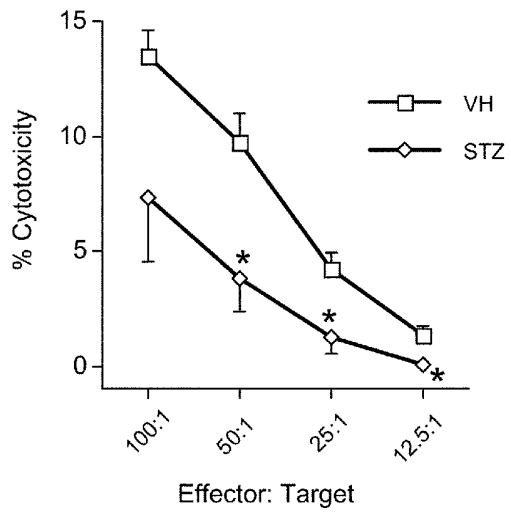

Fig. 3. MLD-STZ treatment decreased splenic NK cell activity in female C57BL/6 mice. Animals were treated with MLD-STZ, and the NK cell activity determined using YAC-1 cells as the target as described. ${ }^{*} \mathrm{P} \leq 0.05$ when compared to vehicle $(\mathrm{VH})$. $\mathrm{N}=8$. cell activity in mice of these strains except that there were significant decreases in the C57BL/6 mice (Fig. 3) with statistically significant changes observed at the E:T ratios of 50:1, 25:1 and 12.5:1. MLD-STZ treatment did not affect the percentages of splenic $\mathrm{NK}\left(\mathrm{NK} 1.1^{+} \mathrm{CD}^{-}\right)$cells in any of the strains (data not shown).

Flow cytometric analysis of spenocytes did not reveal any changes in the percentages of $\operatorname{IgM}^{+}$ $\mathrm{CD}^{-}$B cells, $\mathrm{CD} 4^{-} \mathrm{CD}^{+}{ }^{+} \mathrm{T}$ cells, $\mathrm{CD} 4^{+} \mathrm{CD} 8^{-} \mathrm{T}$ cells, and neutrophils $\left(\mathrm{Gr}-1^{+} \mathrm{MAC}^{-}\right)$in mice of $\mathrm{CD}-1$, $\mathrm{C} 3 \mathrm{H} / \mathrm{HeN}, \mathrm{C} 57 \mathrm{BL} / 6$ and $\mathrm{B} 6 \mathrm{C} 3 \mathrm{~F} 1$ strains following MLD-STZ treatment except that an increase in the neutrophils was observed in the B6C3F1 mice (Table 2). In NOD mice, MLD-STZ treatment induced decreases in the percentages of both $\mathrm{IgM}^{+} \mathrm{CD}^{-} \mathrm{B}$ cells and Gr-1 ${ }^{+}$Mac- $3^{-}$neutrophils, and increases in the percentages of both $\mathrm{CD}_{4}^{+}$ $\mathrm{CD}^{-}$and $\mathrm{CD}^{-} \mathrm{CD}^{+} \mathrm{T}$ cells (Table 2). MLD-STZ treatment did not affect the total number of white blood cells in the spleen (data not shown). When the thymocytes were evaluated in NOD mice, a decrease in the percentages of $\mathrm{CD} 4^{+} \mathrm{CD} 8^{+}$thymocytes while an increase in the percentages of $\mathrm{CD}^{-} \mathrm{CD} 8^{-}$ thymocytes was observed following MLD-STZ treatment (Table 3), suggesting that MLD-STZ treatment might affect T-cell development. A decrease

Table 2. MLD-STZ treatment on the percentages of splenocyte differentials in female mice of various strains

\begin{tabular}{cccccc}
\hline \multirow{2}{*}{ Mouse strains } & \multirow{2}{*}{ Treatment } & IgM $^{+} \mathrm{CD}^{-}$ & $\mathrm{CD}^{-} \mathrm{CD} 8^{+}$ & $\mathrm{CD}^{+} \mathrm{CD}^{-}$ & Gr-1 $^{+} \mathrm{MAC3}^{-}$ \\
\cline { 3 - 6 } & & \multicolumn{3}{c}{$(\%)$} \\
\hline \multirow{2}{*}{ NOD } & VH & $53.83 \pm 2.90$ & $4.91 \pm 0.78$ & $16.6 \pm 2.1$ & $4.09 \pm 1.00$ \\
& MLD-STZ & $39.27 \pm 1.31^{*}$ & $8.76 \pm 0.41^{*}$ & $24.13 \pm 0.61^{*}$ & $1.30 \pm 0.24^{*}$ \\
\hline \multirow{2}{*}{ CD-1 } & VH & $50.26 \pm 1.56$ & $5.12 \pm 0.61$ & $15.43 \pm 1.71$ & $4.92 \pm 1.53$ \\
& MLD-STZ & $52.26 \pm 1.46$ & $4.04 \pm 0.45$ & $14.31 \pm 1.59$ & $3.15 \pm 0.71$ \\
\hline \multirow{2}{*}{ C3H/HeN } & VH & $41.04 \pm 4.38$ & $2.45 \pm 0.42$ & $8.66 \pm 1.16$ & $7.55 \pm 0.66$ \\
& MLD-STZ & $41.39 \pm 1.91$ & $3.41 \pm 0.49$ & $9.32 \pm 0.95$ & $7.05 \pm 1.08$ \\
\hline \multirow{2}{*}{ C57BL/6 } & VH & $43.89 \pm 1.33$ & $4.30 \pm 0.18$ & $14.72 \pm 0.70$ & $1.40 \pm 0.11$ \\
& MLD-STZ & $39.29 \pm 3.67$ & $4.07 \pm 0.40$ & $14.12 \pm 0.44$ & $1.55 \pm 0.23$ \\
\hline \multirow{2}{*}{ B6C3F1 } & VH & $45.67 \pm 4.40$ & $5.33 \pm 0.54$ & $14.44 \pm 0.87$ & $1.62 \pm 0.11$ \\
& MLD-STZ & $49.44 \pm 1.18$ & $5.33 \pm 0.24$ & $15.60 \pm 0.67$ & $2.20 \pm 0.14^{*}$ \\
\hline
\end{tabular}

Animals were sacrificed three weeks after the first STZ injection for NOD and CD-1 mice, and after 16 weeks for mice of other strains; flow cytometric analysis was performed as described. ${ }^{*} P \leq 0.05$ when compared to vehicle $(\mathrm{VH}) . \mathrm{N}=8$. 
Table 3. MLD-STZ treatment on thymus and thymocytes in female NOD and CD-1 mice

\begin{tabular}{ccccccc}
\hline \multirow{2}{*}{ Mouse strains } & \multirow{2}{*}{ Treatment } & \multirow{2}{*}{$\begin{array}{c}\text { Thymus } \\
\text { Weight }(\mathrm{mg})\end{array}$} & $\mathrm{CD}^{+} \mathrm{CD}^{-}$ & $\mathrm{CD}^{-} \mathrm{CD}^{+}$ & $\mathrm{CD}^{+} \mathrm{CD}^{+}$ & $\mathrm{CD}^{-} \mathrm{CD}^{-}$ \\
\cline { 3 - 7 } & & $54.4 \pm 2.6$ & $16.29 \pm 0.52$ & $5.21 \pm 0.57$ & $63.24 \pm 5.12$ & $15.27 \pm 5.44$ \\
\multirow{2}{*}{ NOD } & VH & & \multicolumn{3}{c}{$(\%)$} \\
& MLD-STZ & $36.4 \pm 3.4^{*}$ & $15.79 \pm 1.67$ & $5.57 \pm 0.45$ & $37.75 \pm 2.11^{*}$ & $40.90 \pm 2.29^{*}$ \\
\hline \multirow{2}{*}{ CD-1 } & VH & $46.3 \pm 2.9$ & $16.59 \pm 0.92$ & $5.11 \pm 0.55$ & $71.55 \pm 1.19$ & $6.75 \pm 0.55$ \\
& MLD-STZ & $41.1 \pm 2.2$ & $18.25 \pm 1.48$ & $4.63 \pm 0.53$ & $69.63 \pm 2.84$ & $7.50 \pm 0.98$ \\
\hline
\end{tabular}

Animals were sacrificed three weeks after the first STZ injection, and flow cytometric analysis of thymocytes performed as described. ${ }^{*} P \leq 0.05$ when compared to vehicle $(\mathrm{VH}) . \mathrm{N}=8$.

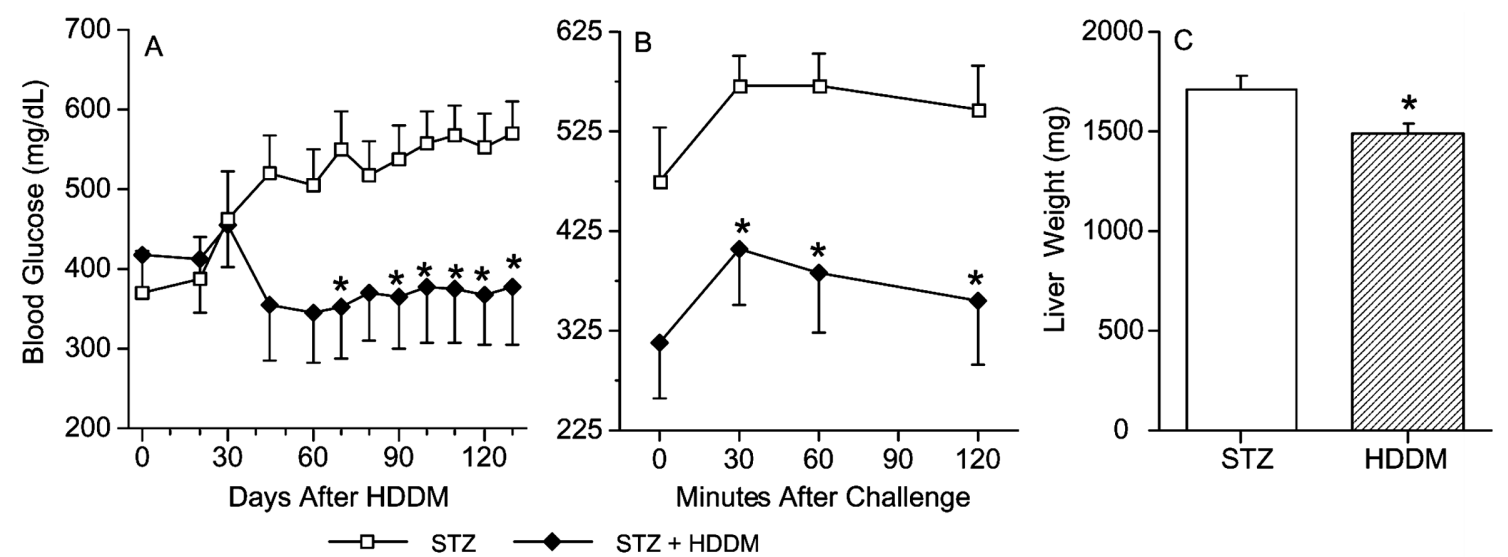

Fig. 4. HDDM reduced blood glucose levels (A), improved glucose tolerance (B), and decreased liver weight (C) in MLD-STZ-treated female B6C3F1 mice. One month after diabetes induction by MLD-STZ, female B6C3F1 mice were dosed with HDDM daily by gavage, and various parameters determined as described. * $P \leq 0.05$ when compared to the control. $\mathrm{N}=8-11$.

in the thymus weight was also observed in MLDSTZ-treated female NOD mice (Table 3). However, MLD-STZ treatment did not affect the percentages of thymocytes in CD-1 mice.

\section{Anti-diabetic effect of HDD and HDDM in female B6C3F1 treated with MLD-STZ}

Above all, the B6C3F1 mice treated with MLD-STZ had moderate diabetes, which was the ideal model to determine the modulatory effect of herb formula on the development of diabetes. One month after diabetes induction by MLD-STZ in female B6C3F1 mice, animals were dosed with HDD or HDDM by daily gavage as described. Treatment with HDD had no effect on the blood glucose levels (data not shown); however, HDDM treatment decreased the blood glucose levels starting at 45 days after the dosing with statistically significant changes observed after 70 days of treatment when compared to the MLD-STZ treatment (Fig. 4A). GTT also suggested that HDDM treatment improved glucose tolerance in these mice (Fig. 4B). In addition, HDDM treatment decreased the liver weight when compared to the MLD-STZ treatment control (Fig. 4C). No significant changes in the body weight (either during the study or at the termination) and kidney weight were produced by HDDM treatment (data not shown).

\section{HDDM had no effect on the immune responses in} female B6C3F1 treated with MLD-STZ

As demonstrated above, MLD-STZ treatment had no substantial effects on the immune response in female B6C3F1 mice. Therefore, we determined the immunomodulatory effect of HDDM in MLD-STZ- 
treated animals, which was important because of the reported effects of these herbs on the immune system. Following immune parameters were measured: spleen weight, total number of splenocytes, NK activity, anti-CD3 antibody-mediated spenocyte proliferation, the percentages of splenic neutrophils, NK cells, $\mathrm{CD}^{+} \mathrm{T}$ cells and B cells $\left(\mathrm{IgM}^{+}\right)$. Treatment with MLD-STZ had no effects on these parameters (data not shown).

\section{DISCUSSION}

Among various strains of mice, different susceptibility to STZ-induced diabetes has been reported, indicating that genetic background is playing an important role in this model (Babaya et al., 2005). In this study, we compared MLD-STZ-induced diabetes in female mice of various strains, including NOD, $\mathrm{CD}-1, \mathrm{C} 3 \mathrm{H} / \mathrm{HeN}, \mathrm{C} 57 \mathrm{BL} / 6$ and B6C3F1. The order of susceptibility to diabetes induction by MLD-STZ treatment was NOD CD-1 > B6C3F1 C3H > C57BL/ 6 . This was surprising since it had been shown that $\mathrm{C} 3 \mathrm{H} / \mathrm{HeN}$ mice were insensitive, while C57BL/6 mice were sensitive, to diabetes induction by STZ (Kaku et al., 1989; Gonzalez et al., 2003). One possible reason was that the mice used in our studies were female since there were sex differences in STZinduced diabetes; for example, female mice were less susceptible than male mice to STZ-induced hyperglycemia in general (Leiter, 1982; Gurley et al., 2006). B6C3F1 mouse is a hybred of male $\mathrm{C} 3 \mathrm{H} /$ $\mathrm{HeN}$ and female C57BL/ 6 mice, and further study is needed to determine if the susceptibility to MLD-STZ-induced diabetes in female B6C3F1 mice is inherited from male $\mathrm{C} 3 \mathrm{H} / \mathrm{HeN}$ mice.

Paik et al. (1980) have shown that thymusdependent functions played an important role in the MLD-STZ-induced diabetes. Nude mice developed milder diabetes than the thymus-intact mice following MLD-STZ treatment (Buschard, 1985). In our studies, MLD-STZ treatment induced an increase in the percentage of $\mathrm{CD}^{-} \mathrm{CD}^{-}$thymocytes and a decrease of the $\mathrm{CD} 4^{+} \mathrm{CD} 8^{+}$thymocytes in female NOD mice. On the other hand, increased percentages of splenic $\mathrm{CD} 4^{+}$and $\mathrm{CD} 8^{+} \mathrm{T}$ cells in these mice were produced following the MLD-STZ treatment. These observations suggested that some immature $\mathrm{CD}^{-} \mathrm{CD}^{-} \mathrm{T}$ cells exited the thymus and matured without further positive and negative selection. MLD-STZ treatment also enhanced $\mathrm{T}$ cell response in female CD-1 mice, which exhibited high STZ susceptibility. In contrast, MLD-STZ treatment decreased $\mathrm{T}$ cell response in female C57BL/ 6 mice, which exhibited the least STZ susceptibility. Thus, changes in $\mathrm{T}$ cell function might be partially responsible for diabetes induction following MLDSTZ treatment, which was consistent with the reports that cyclophosphamide could suppress streptozotocininduced diabetes in mice (Yanagawa et al., 1989) and anti- $\beta$ cell cytotoxic autoimmune response was involved in the diabetes induction (McEvoy et al., 1987). The activity of myeloperoxidase was found to be 3-fold higher in the pancreas following MLDSTZ treatment indicative of an invasion of the pancreatic tissue by polymorphonuclear leukocytes in BALB/c strain (Mabley et al., 2003). However, the contributions of neutrophils to the induction of diabetes by MLD-STZ treatment are currently unclear because MLD-STZ treatment induced an increase of splenic neutrophils in B6C3F1 mice while a decrease in female NOD.

MLD-STZ-induced diabetes in the B6C3F1 mice has been shown be a useful model for the evaluating diabetes exacerbation or attenuation in our studies. Hepatomegaly has been observed in STZ-induced experimental diabetes, which may be due to early hyperplasia, and later decreased apoptosis in liver (Herrman et al., 1999). In our studies, MLD-STZ treatment also induced an increase in the liver weight in both female $\mathrm{B} 6 \mathrm{C} 3 \mathrm{~F} 1$ and $\mathrm{C} 3 \mathrm{H} / \mathrm{HeN}$ mice. Interestingly, the increase of liver weight in MLD-STZ-treated B6C3F1 mice was attenuated following HDDM treatment, which was consistent with reduced blood glucose levels in these mice. The anti-diabetic effect of HDDM was further supported by the findings that HDDM treatment 
could also decrease blood glucose levels in the $\mathrm{db}$ / $\mathrm{db}$ diabetic mice and improve their glucose tolerance (data not shown). In STZ-induced diabetic rats, Yeh et al. (2006) has demonstrated that Yi Yi Ren can regulate lipid and glucose metabolisms. However, Yi Yi Ren-containing HDD had no effect on blood glucose level in MLD-STZ-induced diabetes in B6C3F1 mice. Thus, it was likely that Mai Dong and Shan Zhu Yu were responsible for the antidiabetic effect of HDDM. Mai Dong and its components have blood glucose lowering activity (Chen et al., 1998; Wu et al., 2006). Oleanolic acid, one of the active principles of cornus fruit can increase the release of ACh from nerve terminals, which in turn to stimulate muscarinic M3 receptors in the pancreatic cells and augment the insulin release (Hsu et al., 2006). In addition, Shan Zhu Yu could also increase renal function, and consequently ameliorate glycation-associated renal damage in DN (Xu and Hao, 2004; Yamabe et al., 2007).

In addition to type 1 diabetes, type 2 diabetes was also suggested to be a manifestation of the inflammatory host response (Trabattoni et al., 2006). Furthermore, some herbs (e.g., Panax ginseng) possess both anti-diabetic effect and immune modulatory effects (Cho et al., 2006). Although several herbs (e.g., Huang Qi, Yi Yi Ren, Yin Yang Huo, Dan Shen) in HDDM have immune modulatory effects, we did not observe significant changes in all the immune parameters measured. In future studies, it will be interesting to examine tissue-specific immune responses (e.g., pancreas, kidneys) to determine if immunomodulation is contributing to the antidiabetic effect of HDDM.

In summary, the studies reported here have suggested that MLD-STZ-induced diabetes in female B6C3F1 mice is a useful model to evaluate drug modulation of diabetes, and that the herb formula HDDM possesses anti-diabetic effects. Future studies in DN patients will lend further support that HDDM can be used to treat renal damage in DN as well as reducing blood glucose levels.

\section{ACKNOWLEDGEMENT}

This work was supported in part by the NIEHS Contract ES 55387.

\section{REFERENCES}

Ablamunits V, Quintana F, Reshef T, Elias D, Cohen IR. (1999) Acceleration of autoimmune diabetes by cyclophosphamide is associated with an enhanced IFN-gamma secretion pathway. J. Autoimmun. 13, 383-392.

Abe I, Seki T, Noguchi H, Kashiwada Y. (2000) Galloyl esters from rhubarb are potent inhibitors of squalene epoxidase, a key enzyme in cholesterol biosynthesis. Planta Med. 66, 753-756.

Auttachoat W, Zheng JF, Chi RP, Meng A, Guo TL. (2007) Differential surface expression of CD18 and CD44 by neutrophils in bone marrow and spleen contributed to the neutrophilia in thalidomidetreated female B6C3F1 mice. Toxicol. Appl. Pharmacol. 218, 227-237.

Babaya N, Ikegami H, Fujisawa T, Nojima K, ItoiBabaya M, Inoue K, Ohno T, Shibata M, Ogihara T. (2005) Susceptibility to streptozotocin-induced diabetes is mapped to mouse chromosome 11. Biochem. Biophys. Res. Commun. 328, 158-164.

Buschard K. (1985) The thymus-dependent immune system in the pathogenesis of type 1 (insulindependent) diabetes mellitus. Animal model and human studies. Dan Med. Bull. 32, 139-151.

Cai Q Li XM, Wang HY. (2001) Astragali and Angelica protect the kidney against ischemia and reperfusion injury and accelerate recovery. Chin. Med. J. 114, 119-123.

Chan TM, Leung JK, Tsang RC, Liu ZH, Li LS, Yung S. (2003) Emodin ameliorates glucose-induced matrix synthesis in human peritoneal mesothelial cells. Kidney Int. 64, 519-533.

Chang MS, Oh MS, Kim do R, Jung KJ, Park S, Choi SB, Ko BS, Park SK. (2006) Effects of okchun-san, a herbal formulation, on blood glucose levels and body weight in a model of Type 2 diabetes. J. Ethnopharmacol. 103, 491-495.

Check JB, K'Ombut FO. (1995) The effect on fibrinolytic system of blood plasma of Wister rats after feeding them with Coix mixed diet. East Afr. Med. J. 72, 51-55. 
Chen Yiping, Hu Cuyi, Shen Lingmei. (1987) Observations on clinical and animal experiment of The main therapeutic by benefit qi, promote blood circulation and melt wet on Membranous Glomerulonephritis. J. Trad. Chinese Med. 28, 2-110.

Chen HX, Wang XX, Yan S, Liu XH, Wang L, Shi SQ. (1998) A clinical study of declining urinary protein in diabetes nephropathy with Astragale. Tie Dao Yi Xue 26, 228-229.

Chen WH, Qian H, Wang HZ (1998a) Effect of polysaccharide from ophiopogonis tuber on blood sugar in normal and experimental diabetic mice. Chinese J. Hospital Pharm. 18, 55-60.

Chen J, Wu WH, Yu Y, Yi YH, Lin A, Lin RX. (2000) The effect of Huangqi on renal ischemia reperfusion injury. Chin. J. Urol. 21, 211-212.

Chen CC, Hsu CY, Chen CY, Liu HK. (2008) Fructus Corni suppresses hepatic gluconeogenesis related gene transcription, enhances glucose responsiveness of pancreatic beta-cells, and prevents toxin induced beta-cell death. J. Ethnopharmacol. 117, 483-490.

Cho WC, Chung WS, Lee SK, Leung AW, Cheng CH, Yue KK. (2006) Ginsenoside Re of Panax ginseng possesses significant antioxidant and antihyperlipidemic efficacies in streptozotocin-induced diabetic rats. Eur. J. Pharmacol. 550, 173-179.

Choi SZ, Lee SO, Jang KU, Chung SH, Park SH, Kang HC, Yang EY, Cho HJ, Lee KR. (2005) Antidiabetic stilbene and anthraquinone derivatives from Rheum undulatum. Arch Pharm. Res. 28, 1027-1030.

Chow FY, Nikolic-Paterson DJ, Atkins RC, Tesch GH. (2004) Macrophages in streptozotocin-induced diabetic nephropathy: potential role in renal fibrosis. Nephrol. Dial. Transplant. 19, 2987-2996.

Chung HY, Kim JS, Chung HY, Yokozawa T, Oura H. (1995) The promoting action of magnesium lithospermate B on the kinin-prostaglandin E2 system in the kidney. Pharmacol. Toxicol. 76, 240-244.

Copley JB, Rosario R. (2005) Hypertension: a review and rationale of treatment. Dis. Mon. 51, 548-614.

Dai CS, Liu ZH, Chen HP, Yang JW, Guo XH, Zhuo H. (1999) Effect of rhein in inhibiting the progression of diabetic nephropathy in STZ-induced rats. Chin. J. Nephrol. Dialy Transplant 8, 413-419.

Ding W, Li JZ, Zou WZ, Wang HY. (1998) Astragalus and Angelica reduce TGF-b1 expression in nephrotic rats induced by puromycin aminonucleoside. Chin.
J. Nephrol. 14, 229-232.

Du J, Ling CQ, Chen YA. (2008) Effect of herba epimedil brevicornus and prepared radix rehmannia on glucocorticoid receptor in glucocorticoid receptor down-regulated rats. Zhongguo Zhong Xi Yi Jie He Za Zhi 28, 64-67.

Feng Shuying, Yang Geming, Chen Fan. (1988) Therapy observations of Oxyamyli tectus aldehydum plus low protein diet to Chronic renal failure. J. Fujian Med. drug. 10, 9.

Finne P, Reunanen A, Stenman S, Groop PH, GronhagenRiska C. (2005) Incidence of end-stage renal disease in patients with type 1 diabetes. JAMA. 294, 17821787.

Furness PN, Turner DR. (1987) An assessment of the influence of antigen dose in two new models of chronic eserum sickness glomerulonephritis in the rat. Br. J. Exp. Pathol. 68, 527.

Goel V, Ooraikul B, Basu TK. (1997) Cholesterol lowering effects of rhubarb stalk fiber in hypercholesterolemic men. J. Am. Coll. Nutr. 16, 600-604.

Goel V, Cheema SK, Agellon LB, Ooraikul B, Basu TK. (1999) Dietary rhubarb (Rheum rhaponticum) stalk fibre stimulates cholesterol 7 alpha-hydroxylase gene expression and bile acid excretion in cholesterol-fed C57BL/6J mice. Br. J. Nutr. 81, 65-71.

Gonzalez C, Cuvellier S, Hue-Beauvais C, Lévi-Strauss M. (2003) Genetic control of non obese diabetic mice susceptibility to high-dose streptozotocin-induced diabetes. Diabetologia 46, 1291-1295.

Guo TL, McCay JA, Zhang LX, Brown RD, You L, Karrow NA, Germolec DR, White KL. (2001) Genistein modulates immune responses and increases host resistance to B16F10 tumor in adult female B6C3F1 mice. J. Nutr. 131, 3251-3258.

Guo XH, Liu ZH, Peng A, Bi Y, Wang JP, Zhou H. (2002a) Rhein retards the progression of type 2 diabetic nephropathy in rats. Chin. J. Nephrol. 18, 280-284.

Guo XH, Liu ZH, Wang JP, Zhu MY, Chen HP, Li LS. (2002b) Rhein halts the progression of diabetic nephropathy in NOD mice. Chin. J. Nephrol. Dial. Transplant 11, 11-16.

Gurley SB, Clare SE, Snow KP, Hu A, Meyer TW, Coffman TM. (2006) Impact of genetic background on nephropathy in diabetic mice. Am. J. Physiol. Renal Physiol. 290, F214-222. 
He H, Yang X, Zeng X, Shi M, Yang J, Wu L, Li L. (2007) Protective effect of Liuwei Dihuang decoction on early diabetic nephropathy induced by streptozotocin via modulating ET-ROS axis and matrix metalloproteinase activity in rats. J. Pharm. Pharmacol. 59, 1297-1305.

He W, Sun H, Yang B, Zhang D, Kabelitz D. (1995) Immunoregulatory effects of the herb Epimediia glycoside icariin. Arzneimittel-Forschung 45, 910-913.

Herrman CE, Sanders RA, Klaunig JE, Schwarz LR, Watkins JB 3rd. (1999) Decreased apoptosis as a mechanism for hepatomegaly in streptozotocininduced diabetic rats. Toxicol. Sci. 50, 146-151.

Hidaka Y, Kaneda T, Amino N, Miyai K. (1992) Chinese medicine, Coix seeds increase peripheral cytotoxic T and NK cells. Biotherapy 5, 201-203.

Hovind P, Tarnow L, Rossing P, Jensen BR, Graae M, Torp I, Binder C, Parving HH. (2004) Predictors for the development of microalbuminuria and macroalbuminuria in patients with type 1 diabetes: inception cohort study. BMJ. 328, 1105.

Hsu HY, Lin BF, Lin JY, Kuo CC, Chiang W. (2003) Suppression of allergic reactions by dehulled adlay in association with the balance of TH1/TH2 cell responses. J. Agric. Food Chem. 51, 3763-3769.

Hsu JH, Wu YC, Liu IM, Cheng JT. (2006) Release of acetylcholine to raise insulin secretion in Wistar rats by oleanolic acid, one of the active principles contained in Cornus officinalis. Neurosci. Lett. 404, 112-116.

Hu Y, Liang H, Gong WK, Xu ZF, Zou QL. (2005) The effect of kanglaite injection (KLT) on the proliferation and telomerase activity of rat mesangial cells. Zhongguo Zhong Yao Za Zhi 30, 450-453.

Huang BW, Chiang MT, Yao HT, Chiang W. (2005) The effect of adlay oil on plasma lipids, insulin and leptin in rat. Phytomedicine 12, 433-439.

Jang XF, Wu Y, Tang RY, Fang JP, Sun XH, Li JT. (2003) Effect of Astragalus on expression of intercellular adhesive molecule- 1 in renal ischemia reperfusion injury. Shanghai Med. J. 26, 55-59.

Jeong JC, Hwang WM, Yoon CH, Kim YK. (2001) Salviae radix extract prevents cisplatin-induced acute renal failure in rabbits. Nephron 88, 241-246.

Jiang SZ, Wang GL, Cui CD, Xu H (2004) Effect of total flavonoids of epimedium on gene expression of calmodulin in hypothalamus-pituitary-adrenocortex axis of shenyangxu rats. Chinese J. Appl. Physiol. 8, 32-38.

Jin H, Wang A, Wang Y. (1997) Preventive and therapeutic effects of radix Salviae miltiorrhizae on glycerol-induced acute renal failure in rats. Zhongguo Zhong Yao Za Zhi 22 236-238, 255-256.

Jones CA, Krolewski AS, Rogus J, Xue JL, Collins A, Warram JH. (2005) Epidemic of end-stage renal disease in people with diabetes in the United States population: do we know the cause? Kidney Int. 67, 1684-1691.

Jorsal A, Tarnow L, Frystyk J, Lajer M, Flyvbjerg A, Parving HH, Vionnet N, Rossing P. (2008) Serum adiponectin predicts all-cause mortality and end stage renal disease in patients with type I diabetes and diabetic nephropathy. Kidney Int. 74, 649-654.

Jung M, Lee HC, Ahn CW, Park W, Choi S, Kim H, Cho D, Lee GT, Li HR. (2002) Effective isolation of magnesium lithospermate $B$ and its inhibition of aldose reductase and fibronectin on mesangial cell line. Chem. Pharm. Bull. 50, 1135-1136.

Kaku K, McGill J, Province M, Permutt MA. (1989) A single major gene controls most of the difference in susceptibility to streptozotocin-induced diabetes between C57BL/6J and C3H/HeJ mice. Diabetologia 32, 716-723.

Kim JH, Mun YJ, Im SJ, Han JH, Lee HS, Woo WH. (2001) Effects of the aqueous extract of epimedii herba on the antibody responses in mice. Int. Immunopharmacol. 1, 935-944.

Kim SO, Yun SJ, Jung B, Lee EH, Hahm DH, Shim I, Lee HJ. (2004) Hypolipidemic effects of crude extract of adlay seed (Coix lachrymajobi var. mayuen) in obesity rat fed high fat diet: relations of TNF-alpha and leptin mRNA expressions and serum lipid levels. Life Sci. 75, 1391-1404.

Kim DD, Sánchez FA, Durán RG, Kanetaka T, Durán WN. (2007) Endothelial nitric oxide synthase is a molecular vascular target for the Chinese herb Danshen in hypertension. Am. J. Physiol. Heart Circ. Physiol. 292, H2131-2137.

Kim SO, Yun SJ, Lee EH. (2007a) The water extract of adlay seed (Coix lachrymajobi var. mayuen) exhibits anti-obesity effects through neuroendocrine modulation. Am. J. Chin. Med. 35, 297-308.

Kuo CC, Chiang W, Liu GP, Chien YL, Chang JY, Lee CK, Lo JM, Huang SL, Shih MC, Kuo YH. (2002) 
2,2'-Diphenyl-1-picrylhydrazyl radical-scavenging active components from adlay (Coix lachryma-jobi L. var. ma-yuen Stapf) hulls. J. Agric Food. Chem. 50, 5850-5855.

Leiter EH. (1982) Multiple low-dose streptozotocininduced hyperglycemia and insulitis in C57BL mice: influence of inbred background, sex, and thymus. Proc. Natl. Acad. Sci. USA 79, 630-634.

Li Leishi. (1991) Therapy and functionary mechanism of Chronic Renal Failure treated with Rheum palmatum L. J. Clin. Inter. Med. 8, 12.

Li LS. (1996) Rhubarb in preventing progression of chronic renal disease. Nephrology 2, S146-S151.

Li LS. (1996a) Rheum officinale: a new lead in preventing progression of chronic renal failure. Chin. Med. J. 109, 35-37.

Li X, Kaminski NE, Fischer LJ. (2001) Examination of the immunosuppressive effect of delta9-tetrahydrocannabinol in streptozotocin-induced autoimmune diabetes. Int. Immuno-pharmacol. 1, 699-712.

Like AA, Rossini AA. (1976) Streptozotocin-induced pancreatic insulitis: new model of diabetes mellitus. Science 193, 415-417.

Ma J, Peng A, Chen J, Gu Y, Lu LM, Lin SY. (1996) Different protective effects of Astragalus membranaceus on vasopressin system in experimental nephrotic syndrome and congestive heart failure. Chin. J. Nephrol. 12, 15-19.

Mabley JG, Rabinovitch A, Suarez-Pinzon W, Haskó G, Pacher P, Power R, Southan G, Salzman A, Szabó C. (2003) Inosine protects against the development of diabetes in multiple-low-dose streptozotocin and nonobese diabetic mouse models of type 1 diabetes. Mol. Med. 9, 96-104.

Mantani N, Kogure T, Sakai S, Kainuma M, Kasahara Y, Niizawa A, Shimada Y, Terasawa K. (2002a) A comparative study between excess-dose users and regular-dose users of rhubarb contained in Kampo medicines. Phytomedicine 9, 373-376.

Mantani N, Sekiya N, Sakai S, Kogure T, Shimada Y, Terasawa K. (2002b) Rhubarb use in patients treated with Kampo medicines--a risk for gastric cancer? Yakugaku Zasshi. 122, 403-405.

McEvoy RC, Thomas NM, Hellerström C, GinsbergFellner F, Moran TM. (1987) Multiple low-dose streptozotocin-induced diabetes in the mouse: further evidence for involvement of an anti-B cell cytotoxic cellular auto-immune response. Diabetologia 30, 232-238.

Min Y, Yu L, Yi L. (2003) Effect of a mixture of Astragalus membranaecus and Angelica sinesis on rats with renal tubulointerstitial fibrosis. J. Gui Yang Med. College 28, 134-136.

Oi H, Matsuura D, Miyake M, Ueno M, Takai I, Yamamoto T, Kubo M, Moss J, Noda M. (2002) Identification in traditional herbal medications and confirmation by synthesis of factors that inhibit cholera toxin-induced fluid accumulation. Proc. Natl. Acad. Sci. USA 99, 3042-3046.

Paik SG, Fleischer N, Shin SI. (1980) Insulin-dependent diabetes mellitus induced by subdiabetogenic doses of streptozotocin: obligatory role of cell-mediated autoimmune processes. Proc. Natl. Acad. Sci. USA 77, 6129-6133.

Peng B, Du J, Jia Q, Qiao A, Wu Y, Liu X, Qiang Q. (2001) The effect of salvia miltiorrhiza and shengmai on inflammatory mediator and renal function of post-operative patients with obstructive jaundice. Hиа Xi Yi Ke Da Xuе Хие Вaо. 32, 587-589.

Peng A, Gu Y, Lin SY. (2005) Herbal treatment for renal diseases. Ann. Acad Med. Singapore. 34, 44-51.

Qiao BP, Tang XD, Ruan Q. (2001) Experimental study of compound salvia injection in preventing and treating chronic nephrotoxicity induced by cyclosporin A in rats. Zhongguo Zhong Xi Yi Jie He Za Zhi 21, 611-614.

Reynolds CW, Herberman RB. (1981) In vitro augmentation of natural killer (NK) cell activity. J. Immunol. 126, 1581.

Rossing K, Christensen PK, Hovind P, Parving HH. (2005) Remission of nephrotic-range albuminuria reduces risk of end-stage renal disease and improves survival in type 2 diabetic patients. Diabetologia 48 , 2241-2247.

Seo WG, Pae HO, Chai KY, Yun YG, Kwon TH, Chung HT. (2000) Inhibitory effects of methanol extract of seeds of Job's Tears (Coix lachryma-jobi L. var. mayuen) on nitric oxide and superoxide production in RAW 264.7 macrophages. Immunopharmacol. Immunotoxicol. 22, 545-554.

Shi YQ, Fukai T, Sakagami H, Kuroda J, Miyaoka R, Tamura M, Yoshida N, Nomura T. (2001) Cytotoxic and DNA damage-inducing activities of low molecular weight phenols from rhubarb. Anticancer Res. 21, 
2847-2853.

Shi JF, Zhu HW, Zhang C, Bian F, Shan JP, Lu Wl. (2002) Therapeutic effect of Astragalus on patients with chronic glomerulonephritis. Acta University Medicinalis Secondae Shanghai 22, 245-248.

Shyu ML, Lin BF, Chiang W (1998) Effects of dehulled adlay on allergic responses of sensitized mice. Nutr. Sci. J. 23, 161-170.

Snyder S, Pendergraph B. (2005) Detection and evaluation of chronic kidney disease. Am. Fam. Physician. 72, 1723-1732.

Song H, Wang Z, Zhang F. (2000) Investigation of urinary interleukin-6 level in chronic renal failure patients and the influence of Rheum palmatum in treating it. Zhongguo Zhong Xi Yi Jie He Za Zhi 20, 107-109.

Song F, Qi X, Chen W, Jia W, Yao P, Nussler AK, Sun X, Liu L. (2007) Effect of Momordica grosvenori on oxidative stress pathways in renal mitochondria of normal and alloxan-induced diabetic mice. Involvement of heme oxygenase-1. Eur. J. Nutr. 46, 61-69.

Striker GE, Agodoa LL, Held P, Doi T, Conti F, Striker LJ. (1992) Kidney disease of diabetes mellitus (diabetic nephropathy): perspectives in the United States. J. Diabetes Complications 5, 51-52.

Striker GE, Striker LJ. (1996) Recent advances in diabetic nephropathy: how big a culprit is glucose? Diabetes Metab. 22, 407-414.

Sun Y, Chen B, Jia Q. (2000) Clinical effect of Xinqingning combined low dose continuous gastrointestinal dialysis in treating uremia. Zhongguo Zhong Xi Yi Jie He Za Zhi 20, 660-663.

Takahashi M, Konno C, Hikino H. (1986) Isolation and hypoglycemic activity of coixan A, B, C, glycans of Coix lachrymajobi var. ma-yuen seeds. Planta med. 52, 64-75.

Tegos G, Stermitz FR, Lomovskaya O, Lewis K. (2002) Multidrug pump inhibitors uncover remarkable activity of plant antimicrobials. Antimicrob. Agents Chemother. 46, 3133-3141.

Trabattoni D, Schenal M, Cesari M, Castelletti E, Pacei M, Goldberg B, Gori A, Clerici M. (2006) Low interleukin10 production is associated with diabetes in HIVinfected patients undergoing antiviral therapy. Med. Microbiol. Immunol. 195, 125-132.

Wang Z, Song H. (1999) Clinical observation on therapeutical effect of prepared rhubarb in treating pregnancy induced hypertension. Zhongguo Zhong Xi Yi Jie He Za Zhi 19, 725-727.

Wang HY, Li JZ, Pan JS, Zou WZ, Li XM, Zhang YK. (2002) The effect of Astragali and Angelica on nephrotic syndrome and its mechanisms of action. J. Peking Univ. Health Sci. 34, 542-552.

Wei J, Ni L, Yao J. (1997) Experimental treatment of rhubarb on mesangio-proliferative glomerulonephritis in rats. Zhonghua Nei Ke Za Zhi 36, 87-89.

Weiner DE, Tighiouart H, Elsayed EF, Griffith JL, Salem DN, Levey AS, Sarnak MJ. (2008) The relationship between nontraditional risk factors and outcomes in individuals with stage 3 to 4 CKD. Am. J. Kidney Dis. 51, 212-223.

Woo JH, Li D, Wilsbach K, Orita H, Coulter J, Tully E, Kwon TK, Xu S, (2007) Gabrielson E. Coix seed extract, a commonly used treatment for cancer in China, inhibits NFkappaB and protein kinase C signaling. Cancer Biol. Ther. 6, 2005-2011.

Wu BJ. (edit.) (1982) Pharmacology of Chinese Herba. Beijing, Book concern of people's sanitation., p92.

Wu YG. (1988) Observations and study of Chronic Renal Failure Treated with Rheum Pamatum L. J. Shanghai Trad. Chinese Med. 8, 7.

Wu X, Dai H, Huang L, Gao X, Tsim KW, Tu P. (2006) A fructan, from Radix ophiopogonis, stimulates the proliferation of cultured lymphocytes: structural and functional analyses. J. Nat. Prod. 69, 1257-1260.

Xie JY, Dong JC, Gong ZH. (2006) Effects on herba epimedii and radix Astragali on tumor necrosis factor-alpha and nuclear factor-kappa B in asthmatic rats. Zhongguo Zhong Xi Yi Jie He Za Zhi 26, 723-727.

Xu YJ, Zhang QY, Wu QW. (1997) Effect of Astragalus membranaceus on experimental diabetic renal hypertrophy and microalbuminuria. Acta Universitatis Medicinalis Secondae Shanghai 17, 357-359.

Xu M, Wang YP, Luo WB, Xuan LJ. (2001) Salvianolate inhibits proliferation and endothelin release in cultured rat mesangial cells. Acta Pharmacol. Sin. 22, 629-633.

Xu HQ, Hao HP. (2004) Effects of iridoid total glycoside from Cornus officinalis on prevention of glomerular overexpression of transforming growth factor beta 1 and matrixes in an experimental diabetes model. Biol. Pharm. Bull. 27, 1014-1018.

Xu HB, Huang ZQ. (2007a) Icariin enhances endothelial nitric-oxide synthase expression on human endothelial 
cells in vitro. Vascul. Pharmacol. 47, 18-24.

Xu HB, Huang ZQ. (2007b) Vasorelaxant effects of icariin on isolated canine coronary artery. J. Cardiovasc. Pharmacol. 49, 207-213.

XY, Liu HT, Yu XF. (1999) Observations on influences of treatment with Astragalus injection combined with tetramethylpyrazine injection on changes in plasma lipids, blood viscosity, and renal functions in patients with diabetic nephropathy. Zhongguo Zhong Xi Yi Jie He Ji Jiu Za Zhi 6, 568-569.

Yamabe N, Kang KS, Goto E, Tanaka T, Yokozawa T. (2007) Beneficial effect of Corni Fructus, a constituent of Hachimi-jio-gan, on advanced glycation end-productmediated renal injury in Streptozotocin-treated diabetic rats. Biol. Pharm. Bull. 30, 520-526.

Yanagawa T, Maruyama T, Takei I, Asaba Y, Takahashi T, Ishii T, Kataoka K, Saruta T, Minoshima S, Shimizu N. (1989) The suppressive effect of cyclophosphamide on low-dose streptozotocin-induced diabetes in mice. Diabetes Res. 12, 79-83.

Yang JW, Li LS. (1993) Effect of Rheum officinale on the renal hypertrophy and hyperfiltration in the streptozotocin-induced diabetic rats. Chin. J. Inter. Trad. Western Med. 1, 131-138.

Yang JW, Li LS, Hu WX, Xu RJ. (1994) Inhibitory effect of emodin on compensatory renal hypertrophy in rats. Chin. Pharmacol. Bull. 10, 224-226.

Yang HR, Ma JC, Wang XP, Liu XQ, Zhao ZL. (1997) The effect of Astragalus on immunity in patients with chronic renal failure. Zhong Xi Yi Jie He Shi Yong Lin Chuang Ji Jiu 4, 404-405.

Yang N, Liu X, Lin Q. (1998) Clinical study on effect of Chinese herbal medicine combined with hemodialysis in treating uremia. Zhongguo Zhong Xi Yi Jie He Za Zhi 18, 712-714.

Yang Y, Liu N, Mo Z, Xie J, Liao J, Mo S. (2006) Influence of a Chinese crude drug on Ca2+ influx and efflux in rat visceral organs: investigation and evaluation by 45Ca. Appl. Radiat. Isot. 64, 241-246.

Yeh PH, Chiang W, Chiang MT. (2006) Effects of dehulled adlay on plasma glucose and lipid concentrations in streptozotocin-induced diabetic rats fed a diet enriched in cholesterol. Int. J. Vitam Nutr. Res. 76, 299-305.

Yokozawa T, Fujioka K, Oura H, Nonaka G, Nishioka I. (1991) Effects of rhubarb tannins on uremic toxins. Nephron 58, 155-160.
Yokozawa T, Lee TW, Oura H, Nonaka G, Nishioka I. (1992) Effect of magnesium lithospermate B in rats with sodium-induced hypertension and renal failure. Nephron. 60, 460-465.

Yokozawa T, Chen CP. (2000) Role of Salviae Miltiorrhizae Radix extract and its compounds in enhancing nitric oxide expression. Phytomedicine 7 , 55-61.

Yu YS, Li LS, Zhang X. (1995) Clinical effects of rheum and captopril on preventing progression of chronic renal failure. Chin. J. Nephrol. Dial. Transplant 4, 3235.

Yu L, Zhang JF, Li JZ, Zhao AY, Zhou WZ, Wang HY. (2000) Astragalus and Angelica retard the progressive tubulointerstitial lesions in puromycin nephropathy. Chin. J. Nephrol. 16, 283-286.

Yu YM, Chang WC, Liu CS, Tsai CM. (2004) Effect of young barley leaf extract and adlay on plasma lipids and LDL oxidation in hyperlipidemic smokers. Biol. Pharm. Bull. 27, 802-805.

Zhang DX, Jin ZS, Tian SM. (1984) The injection of Radiz Astragali treated 30 cases of Chronic nephritis with albuminuria and azotemia. J. Shanghai Trad. Chinese Med. 9.

Zhang ZJ, Cheng WW, Yang YM. (1994) Low-dose of processed rhubarb in preventing pregnancy induced hypertension. Zhonghua Fu Chan Ke Za Zhi 29, 463464.

Zhang G, el Nahas AM. (1996) The effect of rhubarb extract on experimental renal fibrosis. Nephrol. Dial. Transplant 11, 186-190.

Zhang J, Liu Z, Chen Z, Li Y, Li L. (1999) Effect of rhein on glucose transporter- 1 expression and its function in glomerular mesangial cells. Chin. Med. J. 112, 1077-1079.

Zhang J, Liu ZH, Liu H, Li YJ, Li LS. (2000) Regulation of the expression and function of glucose transporter by TGF-b1 and high glucose in mesangial cells. Chin. Med. J. 113, 508-513.

Zhao Yihuan, Li Shishu. (1983) Primary observations on Therapy of Astragalus Membranacus to (Masugi nephritis) (experimental resist-kidney antibody nephritis?) in Rabbits. Chin. J. Integ. Trad. Western Med. 3, 302.

Zhao YQ, Li GQ, Guo CX, Lian X. (2000) Evaluation the effect of TNF-alpha, RBC immunologic function and improvement renal function by Astragalus root 
in patients with Chronic renal failure. J. Mudanjiang Med. Coll. 21, 5-6.

Zhao F, Tang YZ, Liu ZQ. (2007) Protective effect of icariin on DNA against radical-induced oxidative damage. J. Pharm. Pharmacol. 59, 1729-1732.

Zheng Jianfeng, Chen Siyuan. (1993) Observations on Therapeutic Effects of Huangdan Decoction and Tripterygium Wilfordii compound Tablet on Membranous Glomerulonephritis in Rats. Chin. J Integ. Trad. Western Med. 13, 215-218.

Zheng Jianfeng, Hong Shuyun, Chen Siyuan. (1997) Anti-lipid Peroxidization Effect of Huangdan on Chronal Failure in Rats. J. Tongji Medical University 17, 221-224.

Zheng Jianfeng, Hong Shuyun, Chen Siyuan. (1998) Clinical study of Chronic Renal Failure with Huangdan Decoction. The treatise compilation of an academic meeting of 5th national nephrology of Chinese Medical Association. Beijing, Sep.

Zhu JM, Liu ZH, Huang YF, Chen HP, Zhou H, Wang JP. (2002) Therapeutic effect of rhein on diabetic nephropathy in $\mathrm{db} / \mathrm{db}$ mice. Chin. J. Nephrol. Dial. Transplant 11, 3-10.

Ziyadeh FN, Hoffman BB, Han DC, Iglesias-De La Cruz MC, Hong SW, Isono M, Chen S, McGowan TA, Sharma K. (2000) Long-term prevention of renal insufficiency, excess matrix gene expression, and glomerular mesangial matrix expansion by treatment with monoclonal antitransforming growth factor-beta antibody in $\mathrm{db} / \mathrm{db}$ diabetic mice. Proc. Natl. Acad. Sci. USA 97, 8015-8020.

Ziyadeh FN, Wolf G. (2008) Pathogenesis of the podocytopathy and proteinuria in diabetic glomerulopathy. Curr. Diabetes Rev. 4, 39-45. 